\title{
EVALUASI POLA SPASIAL TUBERKULOSIS DI BANYUMAS MENGGUNAKAN FUZZY SET BERBASIS SISTEM INFORMASI GEOGRAFIS
}

\author{
Mutia Nur Estri dan Supriyanto \\ Program Studi Matematika, Fakultas Sains dan Tekink \\ Universitas Jenderal Soedirman, Purwokerto
}

\begin{abstract}
Tuberculosis prevention in Banyumas which still become problem is the lowness of case finding of positive Tuberculosis victims. It is caused by lack of supporting aspect from community. For 2007 there are 4229 cases and 367 of them are active patients who take medical treatment.
\end{abstract}

This research aim to for: a). to making a map of thematic which good for knowing pattern spreading of disease of TB in Banyumas, b). knowing factors having an effect on to spreading of disease of TB in Banyumas, and $c$ ). knowing subdividing pattern (regional clustering) pursuant to spreading of disease of TB in Banyumas.

This research uses method of fuzzy set with approach of Geographical Information System.Results which are obtained from this research are: a) Tuberculosis event is significantly related to poverty. It is caused by low education level and occupation of Tuberculosis victim. b) Tuberculosis spreading is not related directly to population density, age, disease status of Tuberculosis victims and distance from medical facility. Spatial distribution pattern of Tuberculosis does not follow a certain pattern and c) Tuberculosis clustering tend to cluster at poor area in the city and spread follows the river flow.

Keywords. tuberculosis, clustering, GIS, fuzzy set, spatial.

\section{A. Pendahuluan}

Tuberkulosis (TB) masih merupakan ancaman kesehatan utama di negara berkembang. Indonesia menempati posisi ketiga dalam jumlah kasus setelah India dan China. Menurut Depkes RI (2007), dalam pengendalian TB memang perlu ada terobosan metode agar bisa lebih efektif. Dengan dukungan kemajuan teknologi informasi seperti saat ini, salah satu tool potensial untuk mengintegrasikan adalah sistem informasi geografis (SIG). Sistem informasi geografis merupakan seperangkat tatanan dan prosedur yang meliputi perangkat lunak, perangkat keras untuk mengolah data/informasi dalam konteks spasial (keruangan) untuk mendukung pengambilan keputusan. Model aplikasi berbasis

Diterima 8 Januari 2009, disetujui untuk dipublikasikan 21 April 2009. 
web tidak lagi menjadi aplikasi stand-alone yang terisolir dan merepotkan untuk diupdate.

Disamping jenis aplikasi, data mengenai penyebaran penyakit TB pun bisa menjadi bahan kajian spasial. Salah satu contohnya adalah determinan fase kesehatan penderita. Pendekatan SIG tentang variabel jarak dari fasilitas kesehatan terhadap episentrum belum memberikan kesimpulan yang seragam. Adanya integrasi serta mekanisme sharing data diharapkan akan menghasilkan banyak lesson learnt yang dijadikan pelajaran agar Indonesia semakin tangguh (resilience) menghadapi Indonesia bebas TB.

Penelitian ini bertujuan untuk membuat peta penyebaran penyakit TB yang dapat digunakan sebagai gambaran deskriptif mengenai distribusi serta penyebaran penyakit menular. Peta yang akurat dalam bentuk sekuens diharapkan dapat menjawab pertanyaan apa yang terjadi dan mengapa. Peta tematik yang ada di seksi surveilans bisa menggambarkan apa yang terjadi belum sampai ke mengapa. Tujuan kedua yang dicapai adalah menentukan faktor-faktor yang mempengaruhi pola penyebaran TB di Banyumas, serta yang ketiga adalah menentukan pola penyebaran penyakit TB di Banyumas.

\section{B. Metodologi Penelitian}

Tahapan dalam analisis data dengan menggunakan metode SIG dapat dijelaskan sebagai berikut :

1. Penghitungan nilai MF dilakukan dalam Sistem Informasi Geografis (SIG) berbasis vektor. Dengan demikian, data yang digunakan terdiferensi dengan baik pada koordinat bumi. Dalam penelitian ini digunakan sistem koordinat Universal Transverse Mercator (UTM).

2. Peta satuan lokasi yang telah dibuat manuskripnya didigitasi dalam SIG vektor. Kemudian, basis data penelitian (hasil survei) dikelompokkan ke dalam masing-masing kategori grupnya, dan diinput ke dalam SIG sebagai data atribut. Proses rating mula-mula dilakukan berdasarkan metode faktor pembatas (FAO) dalam tabel atribut SIG tersebut pada masing-masing satuan lokasi. 
3. Dengan menggunakan SIG dalam evaluasi kesesuaian lokasi, proses integrasi basis data yang kompleks dapat dilakukan dengan efektif baik dari segi prosedur kerja (proses input, pengolahan dan analisa data, sampai pada visualisasi), luarannya, maupun scope dan aplikasi penyebarannya. Kemudian, sistem informasi geografi dapat menyajikan output dengan format yang mudah dimengerti, dan mudah dimutakhirkan bilamana di kemudian hari terdapat perubahan atau penambahan informasi yang berhubungan evaluasi lokasi dan perencanaan di wilayah penelitian.

4. Evaluasi kesesuaian lokasi yang dilakukan melalui pendekatan Membership Function setelah evaluasi dengan pendekatan faktor pembatas dimaksudkan untuk memberikan gambaran tentang tingkat kesesuaian lokasi secara kuantitatif pada satu satuan luas. Penentuan nilai evaluasi tingkat kesesuaian lokasi melalui pendekatan Fuzzy Set menggunakan nilai kuantitatif yang secara langsung dapat menggambarkan kondisi aktual mengenai tingkat penyebaran TB di lokasi yang dapat dicapai.

\section{Hasil dan Pembahasan}

Wilayah Kabupaten Banyumas terletak di dalam Wilayah Propinsi Jawa Tengah. Kota Purwokerto adalah Ibukota Pemerintah Kabupaten Banyumas. Kabupaten Banyumas secara astromonis terletak antara $7^{0}-30^{0}$ Lintang Selatan dan lebih kurang $109^{0}-130^{\circ}$ Bujur Timur.

Dinas Kesehatan Kabupaten Banyumas mengungkapkan sepanjang tahun 2007 terdapat sebanyak 4229 orang menderita penyakit tuberkulosis. Jumlah itu didapat dari laporan BP4, pusat kesehatan masyarakat (puskesmas), klinik pengobatan swasta, RSUD Banyumas dan RSUD Margono Sukaryo. Sayangnya, banyak penderita yang malas untuk berobat secara intensif. Mereka umumnya hanya berobat dalam dua bulan pertama dari maksimal selama enam bulan. Jika sampai enam bulan tak sembuh juga, maka virus tuberkulosis sudah kebal dan sangat berpontensi menulari orang-orang. Dari 4229 penderita, hanya 367 penderita yang rajin berobat intensif. 
Berdasarkan data dari Balai Pengobatan Penyakit Paru-paru (BP4) Purwokerto, penderita TBC untuk setiap tahunnya meningkat hampir merata di tiap kecamatan di Kabupaten Banyumas. Bahkan penderita yang resisten (kebal terhadap obat-obatan) juga meningkat, hal ini disebabkan karena Penderita TBC tidak teratur dalam menjalani pengobatan atau pindah berobat tanpa sepengetahuan ahlinya. Data pasien di BP4 untuk tahun 2007 mengalami peningkatan, dari 356 penderita di tahun 2006 menjadi 443 di tahun 2007. Untuk Jawa Tengah, penderita TBC Kabupaten Banyumas menempati urutan tertinggi disusul Kabupaten Brebes masuk urutan kedua sebanyak 235 penderita di tahun 2007 yang tahun sebelumnya hanya ada 120 penderita. Urutan ketiga Kabupaten Cilacap 208 penderita dari 182 penderita di tahun 2006.

\section{Tingkat Kesesuaian Faktor Penyebaran TB dengan Faktor Pembatas Sederhana dan Fuzzy Set}

Evaluasi kesesuaian lokasi yang dilakukan melalui pendekatan Fuzzy Set (Membership Function) setelah evaluasi lokasi penderita TB dengan pendekatan faktor pembatas (FAO) dimaksudkan untuk memberikan gambaran tentang tingkat kesesuaian penyebaran penyakit TB secara kuantitatif pada satu satuan lokasi (wilayah). Sesungguhnya arahan penggunaan koordinat pasien yang diperoleh melalui pendekatan pembatas sederhana ini telah memadai untuk dijadikan dasar dalam menentukan tingkat penyebaran penyakit pada wilayah sekitarnya. Namun demikian, untuk lebih informatifnya gambaran tentang tingkat kesesuaian lokasi pada suatu wilayah, maka gabungan evaluasi kesesuaian tersebut menjadi lebih diperlukan. Hal ini dimungkinkan karena evaluasi tingkat kesesuaian posisi melalui pendekatan Fuzzy Set telah menggunakan nilai kuantitatif yang secara langsung dapat menggambarkan kondisi aktual mengenai tingkat penyebaran penyakit TB.

lokasi yang dapat dicapai. 


\section{Kesesuaian Lokasi Penderita TB}

Dengan menggunakan data yang diperoleh dari penelitian ini dapat dianalisis untuk menentukan faktor-faktor yang berpengaruh terhadap penyebaran penyakit TB di Banyumas. Untuk menentukan nilai MF, ditentukan bahwa posisi penderita (sebagai koordinat) diasumsikan sebagai variabel dependen, yang bergantung pada variabel independennya yaitu usia, pekerjaan, layanan kesehatan, dan tingkat pendidikan.

Informasi awal sebelum dilakukan analisis merupakan peta administratif Banyumas, dimana peta ini akan dijadikan layer awal pembentukan pola sebaran penyakit TB. Layer ini kemudian akan digabungkan dengan hasil dari output MapInfo yang berupa peta.

Tabel 1. Kelompok FAO dan nilai MF dari masing-masing lokasi penderita TB

\begin{tabular}{|l|l|l|l|}
\hline Wilayah & $\begin{array}{l}\text { Kesesuaian } \\
\text { Lokasi }\end{array}$ & Kategori & $\begin{array}{l}\text { Interval } \\
\text { Nilai MF }\end{array}$ \\
\hline $\begin{array}{l}\text { Wangon, Somagede, Ajibarang, } \\
\text { Gumelar, Cilongok, Kedungbanteng }\end{array}$ & $\mathrm{N}$ & Netral & 0 \\
\hline $\begin{array}{l}\text { Lumbir, Rawalo, Kebasen, Kemranjen, } \\
\text { Sumpiuh, Kalibagor, Patikraja, } \\
\text { Purwojati, Sumbang }\end{array}$ & Sedang & $0,4-0,46$ \\
\hline $\begin{array}{l}\text { Jatilawang, Pekuncen, Sokaraja, S2 } \\
\text { Kembaran, Tambak, Karangwelas, } \\
\text { Baturaden, Purwokerto Barat }\end{array}$ & Tinggi & $0,62-0,80$ \\
\hline $\begin{array}{l}\text { Banyumas, Purwokerto Selatan, } \\
\text { Purwokerto Timur, Purwokerto Utara }\end{array}$ & S1 & $\begin{array}{l}\text { Sangat } \\
\text { Tinggi }\end{array}$ & 1 \\
\hline
\end{tabular}




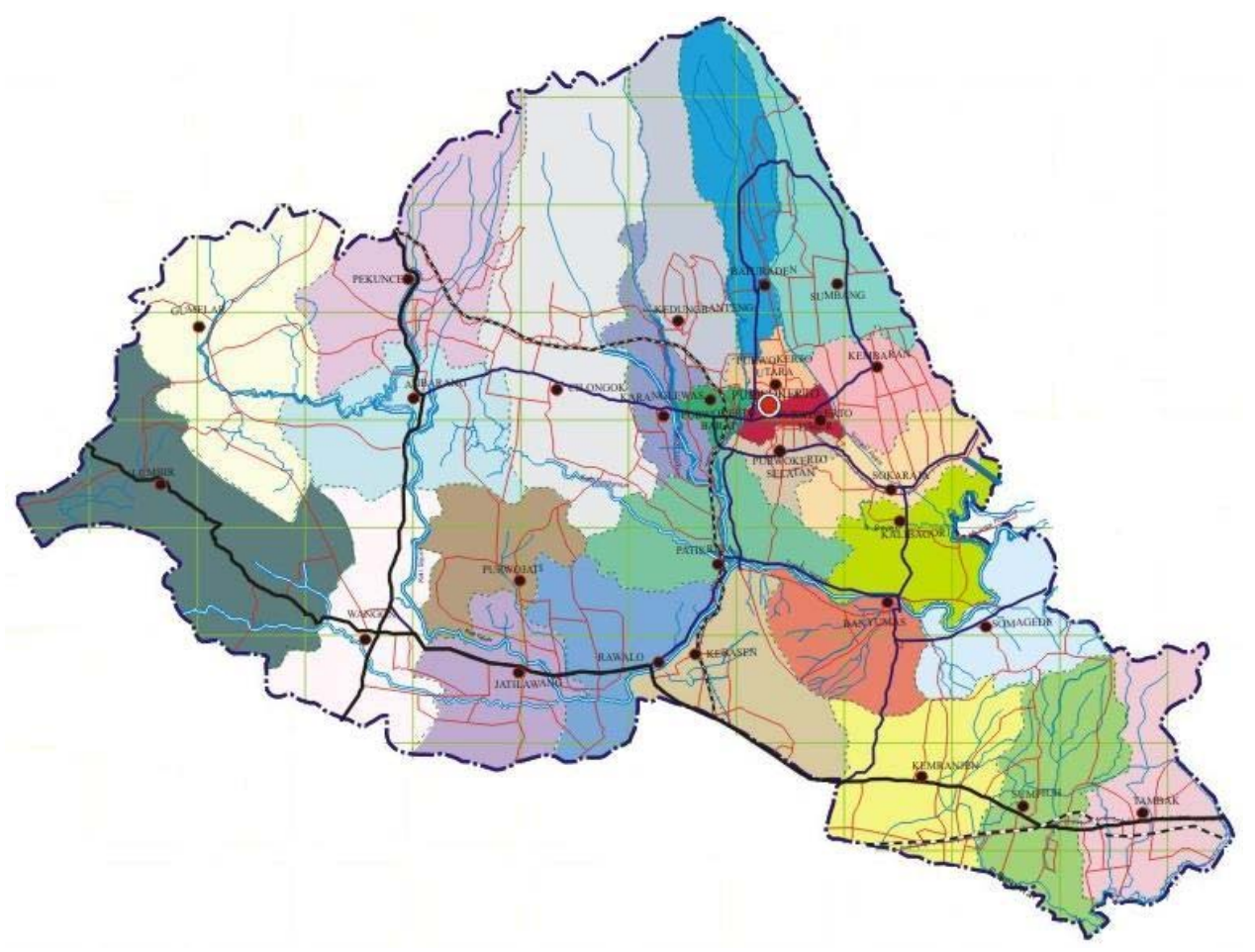

Gambar 1. Peta sebaran penyakit TB di Banyumas.

Dari Tabel 1 dan Gambar 1 diperoleh informasi bahwa wilayah perkotaan, yaitu Kota Purwokerto (selain Purwokero Barat) dan Banyumas (kelompok S1) merupakan wilayah yang paling tinggi tingkat penyebaran TB di Kabupaten Banyumas. Dari hasil pengelompokan berdasarkan nilai Mfnya, wilayah ini dipengaruhi oleh semua faktor yang ada. Dari faktor-faktor usia, pendidikan, pekerjaan, dan unit pelayanan, yang memiliki korelasi paling tinggi adalah faktor pekerjaan dengan faktor pendidikan. Korelasi antar faktor ini menyebabkan ledakan jumlah pasien. Hasil interaksi yang dapat disimpulkan adalah pasien dengan pendidikan rendah dan pekerjaan yang menghasilkan pendapatan minimal akan memacu terjadinya penyebaran penyakit TB. Hal ini dapat dibenarkan dari asumsi pemerintah bahwa kemiskinan di perkotaan merupakan salah satu faktor terpenting yang harus diwaspadai oleh dinas kesehatan. Informasi kedua yang dapat diambil adalah korelasi antara faktor unit pelayanan kesehatan dengan usia. Di wilayah perkotaan ternyata ada korelasi positif antara usia penderita dengan unit pelayanan yang digunakan. Penderita anak-anak lebih banyak menggunakan 
fasilitas kesehatan dari klinik swasta dan usia dewasa memilih rumah sakit sebagai sarana pengobatannya. Informasi berikutnya yang dapat diambil dari pengelompokan adalah korelasi antara pekerjaan dengan unit pelayanan. Rata-rata penderita yang bekerja sebagai buruh harian lepas lebih suka berobat ke puskesmas daripada unit kesehatan yang lain.

Kelompok kedua (S2) adalah wilayah Purwokerto Barat, Baturraden, Kembaran, Karangwelas, Sokaraja, Pekuncen, Tambak, dan Jatilawang. Di wilayah ini dari empat faktor yang ada, terdapat tiga faktor yang mempengaruhi penyebaran TB di Banyumas, yaitu pendidikan, pekerjaan, dan unit pelayanan. Dari tiga faktor tersebut terdapat hubungan (korelasi) antar faktor sebagai berikut. Hanya ada dua jenis korelasi faktor yang perlu dicermati, yaitu korelasi antara pendidikan dengan pekerjaan dan korelasi antara pekerjaan dan unit pelayanan.

Kelompok ketiga (S3) adalah wilayah Sumbang, Purwojati, Patikraja, Kalibagor, Sumpiuh, Kemranjen, Rawalo, dan Lumbir. Di wilayah ini faktor yang berpengaruh adalah pendidikan dan pekerjaan penderita. Hasil korelasi yang didapat adalah adanya korelasi yang kuat antara tingkat pendidikan dengan pekerjaan. Hal ini berarti bahwa kemiskinan masih menjadi faktor utama sebagai penyebab penyebaran penyakit TB di Banyumas.

Kelompok yang terakhir adalah kelompok netral $(\mathrm{N})$. Wilayah yang termasuk kelompok ini meliputi kecamatan Kedungbanteng, Gumelar, Ajibarang, Somagede, dan Wangon. Di wilayah ini faktor-faktor usia, pendidikan, dan unit pelayanan kesehatan tidak berpengaruh secara signifikan. Faktor yang berpengaruh hanyalah pekerjaan penderita.

\section{Analisis Spasial Penderita TB}

Analisa yang digunakan adalah analisa spasial dengan SurGe untuk mengetahui pengelompokan TB dan mengetahui jarak antara tempat tinggal kasus dengan sarana pelayanan kesehatan, serta analisa spatially weighted regression menggunakan MapInfo untuk mengetahui ada tidaknya hubungan antar variabel bebas (kepadatan penduduk, kemiskinan dan sarana pelayanan kesehatan) terhadap variabel tergantung (kejadian TB). Hasil uji analisa spatially weighted 
regression (spatial error model) dengan SurGe menunjukkan bahwa tidak ada hubungan yang bermakna antara kepadatan penduduk dengan kejadian TB di kabupaten Banyumas $(t=-0,667 \mathrm{p}=0,506(\mathrm{p}>0,05))$. Kejadian TB berhubungan erat dengan kemiskinan $(\mathrm{t}=-1,992 ; \mathrm{p}=0,049(\mathrm{p}<0,05))$ dan kejadian TB tidak mengikuti pola distribusi spasial tertentu $(\mathrm{p}=0,622(\mathrm{p}>0,05))$.

Hubungan tingkat kepadatan penduduk dengan kejadian TB diperoleh $\mathrm{z}$ value $=-1,529 \mathrm{p}=0,126(\mathrm{p}>0,05)$, hubungan kemiskinan dengan kejadian TB diperoleh diperoleh $\mathrm{z}$ value $=3,502 \mathrm{p}=0,0004(\mathrm{p}<0,05)$, hubungan status penyakit terhadap kejadian TB hasil analisis diperoleh $\mathrm{z}$ value $=-1,113 \mathrm{p}=0,909$ ( $>00,05)$, hubungan jarak ke fasilitas pelayanan kesehatan terhadap kejadian TB diperolah nilai $\chi 2=0,21$ dengan nilai probabilitas ( $p$ value $)=0,65$ atau $p>0,05$.

Gambar 2 merupakan mapping dari pengclusteran penderita TB berdasarkan factor geografisnya yang dipengaruhi oleh empat variabel dependen usia, pekerjaan, pendidikan, dan sarana unit pelayanan kesehatan.

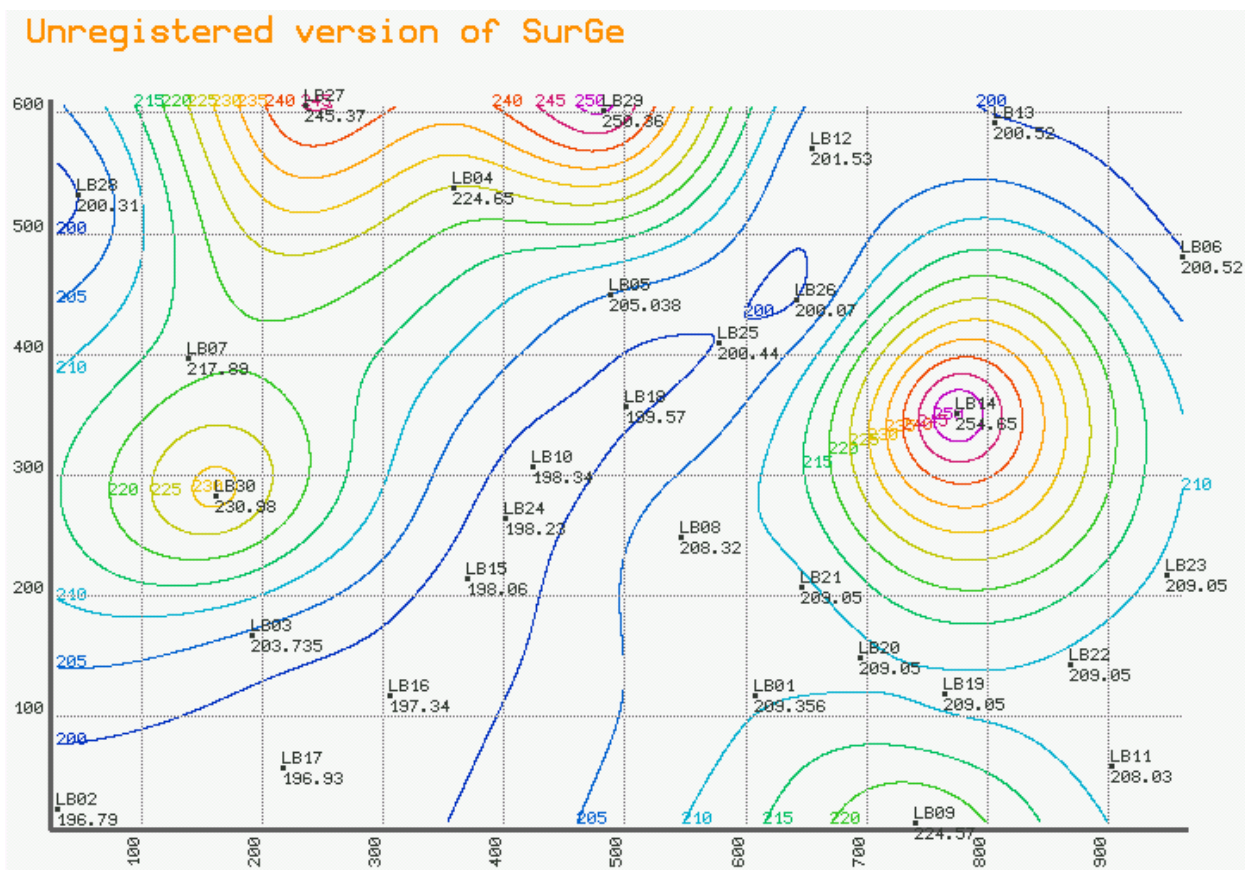

Gambar 2. Mapping pengclusteran wilayah 
Pengclusteran TB cenderung pada daerah miskin di perkotaan dan menyebar mengikuti arah jalan. Wilayah sisi timur dan utara cenderung memiliki angka kasus yang lebih tinggi.

Berdasarkan hasil SurGe menggunakan Space-Time Permutation Model (Likelihood Ratio Test) didapatkan lima cluster. Cluster 1 berpusat pada koordinat $(-7.767990 \mathrm{~s}, 110.391840 \mathrm{E})$ dengan radius $2,18 \mathrm{~km}$. Cluster ini meliputi wilayah Kota Purwokerto, cluster kedua yaitu cluster yang berpusat pada koordinat ($7.641750 \mathrm{~s}, 110.382630 \mathrm{E}$ ) dengan radius seluas $2,11 \mathrm{~km}$. Wilayah cluster kedua berada pada kecamatan Kebasen, yang berbatasan dengan Kabupaten Cilacap. Cluster ke tiga dann ke empat sedikit melebar di dua kecamatan, yaitu kecamatan Gumelar dan Pakuncen yang berbatasan dengan Kabupaten Brebes. Cluster ke lima adalah wilayah kecamatan Lumbir.

\section{Kesimpulan dan Saran}

\section{Kesimpulan}

a. Kejadian TB berhubungan dengan kemiskinan secara signifikan, yang disebabkan karena tingkat pendidikan yang rendah dan pekerjaan penderita TB.

b. Penyebaran TB tidak berhubungan langsung dengan tingkat kepadatan penduduk, usia, status penyakit, dan jarak ke fasilitas pelayanan.

c. Pola distribusi spasial TB tidak mengikuti pola tertentu.

d. Pengclusteran TB cenderung pada daerah miskin dan menyebar mengikuti arah arus sungai.

\section{Saran}

Saran yang dapat diberikan kepada instansi pemerintah adalah perlu diperhatikan masalah kemiskinan di perkotaan sebagai faktor utama penyebaran penyakit TB di Banyumas. Untuk penelitian selanjutnya perlu didukung data tentang pola penyebaran penduduk yang positif terinfeksi TB agar pergerakan penyebarannya dapat dipetakan secara jelas dan akurat. 


\section{DAFTAR PUSTAKA}

Baja, S., Land Resource Assesment: Lecture Notes. School of Geosciences, The University of Sydney, Sydney, 2000.

Baja, S., Chapman, D.M. and Dragovich, D., A Conceptual model for assessing agricultural land suitability at a catchment level using a continous approach in GIS, Proceeding of the Geospatial Information and Agriculture Conference, 17-19 July 2001, Sydney. NSW Departement of Agriculture, Sydney, 2001a, 828-841.

Baja, S., Chapman, D.M. and Dragovich, D., A Conceptual model for defining and assessing land management units using a fuzzy modeling approach in GIS environment. Environmental Management, 29(2002), 647-661.

Baja, S., Chapman, D.M. and Dragovich, D., Land use and soil erosion in land suitability assessment: a new approach from quantitative and spatial perspectives applied to the Sidney Region, Australia. Environment and Planning B, 29(2002), 3-20.

Baja, S., Chapman, D.M. and Dragovich, D., Using GIS and Remote Sensing for assessing and mapping the present status of land use and land qualities in the lower Hawkesbury-Nepean Catchment, Australia. Geocarto International 17(2002), 15-24.

Bruce, A and George Coghill, Implementation Parallelisations in a Fuzzy Qualitative Reasoning Engine, Proceeding of the 2005 UK Workshop on Computational Intelligence, London, UK.

Burrough, P.A. and McDonnel, R. A., Principal of Geographical Information Systems. Oxford University Press Inc., New York, 1998.

Davidson, D.A., Theocharopoulos, S.P., and Bloksma, R.J., A Land Evaluation Project in Greece using GIS and based on Boolean and fuzzy set methodologies, International Journal of Geographic Information Systems, 8(1994), 369-384.

Depkes RI, Pointers Menkes Menyambut Hari TB Sedunia 2007, 2007, www.depkes.go.id, diakses tanggal 2 Juni 2007. 
Lekhavat, L. dan CJ Hinde, Fuzzy Reasoning in Computer Go Opening Stage Strategy, Proceeding of the 2005 UK Workshop on Computational Intelligence, London, UK, 2005.

Siswono, Waspada, Kuman Tuberkulosis di Sekitar Kita, 2006, www.gizi.net., diakses tanggal 2 Juni 2007. 
